\title{
Pre-Mesozoic basement of Tvarditsa Stara Planina Mountain, Central South Bulgaria: U-Pb geochronology and regional implication
}

\section{Домезозойски фундамент на Твърдишка Стара планина, Централна Южна България: U-Pb геохронология и регионално значение}

\author{
Wolfgang Dörr', Anna Lazarova ${ }^{2}$, Ianko Gerdjikov ${ }^{3}$ \\ Волфганг Дьор ${ }^{1}$, Анна Лазарова ${ }^{2}$, Янко Герджиков \\ ${ }^{1}$ Institute of Geosciences, Goethe University, Altenhöferallee 1, 60438 Frankfurt am Main, Germany \\ ${ }^{2}$ Geological Institute, Bulgarian Academy of Sciences, 1113 Sofia; E-mail: alazarova@geology.bas.bg \\ ${ }^{3}$ Sofia University St Kliment Ohridski, 15 Tsar Osvoboditel Blvd., 1504 Sofia
}

\begin{abstract}
The easternmost coherent tract of the pre-Mesozoic basement of the Carpatho-Balkanide belt is exposed in Tvarditsa Stara Planina Mountain. Two metamorphic units - the Lazovo and Shivachevo complexes as well as the Tvarditsa pluton were distinguished, as their ages are still not well constrained. Here, we present U-Pb (ID-TIMS) data for the Shivachevo complex and the Tvarditsa pluton, putting this information in the regional context of the late Variscan geodynamic evolution of the region.
\end{abstract}

Keywords: pre-Mesozoic basement, Tvarditsa Stara Planina Mountain, U-Pb (ID-TIMS) zircon geochronology.

\section{Introduction}

The structural and geochronological data accumulated in the recent years show that the pre-Mesozoic basement of the Carpatho-Balkanides comprises various in age and nature rocks, constituting the Variscan orogen of Southeastern Europe. The easternmost coherent tract of the basement is exposed in Tvarditsa Stara Planina Mountain. It incorporates two metamorphic units - the Lazovo and Shivachevo complexes as well as the Tvarditsa pluton (Ivanov et al., 1974). The observed field relationships between these rocks and the Permian-Mesozoic cover clearly evidence the pre-Permian age of the basement, but precise geochronological data for the protoliths and metamorphic transformations are still lacking. In this study we present U-Pb (IDTIMS) data from samples of the Shivachevo complex and Tvarditsa pluton, putting this information in the regional context of the late Variscan and Alpine geodynamic evolution of the region.

\section{Geological setting}

The lowermost structural position within the metamorphic basement is occupied by the Lazovo com- plex. The overview of the available data indicates that it is a compositionally variegated polymetamorphic unit, affected by at least three metamorphic events - first HP-HT, second LP-HT and later, related to the Alpine tectonics (Georgiev et al., 2006; Statelova, 2006). The complex comprises metaigneous (intermediate, mafic and ultramafic) and metasedimentary rocks, poorly studied in terms of protoliths, metamorphism and structural relationships. Quite provisional are the Cadomian zircon LA-ICP-MS protolith ages of ca. $600 \mathrm{Ma}$, obtained from gneisses in the eastern part of the complex (Statelova et al., 2011) as well as the ${ }^{40} \mathrm{Ar} /{ }^{39} \mathrm{Ar}$ age of ca. 338 Ma of syn-metamorphic white micas from schists (Statelova, 2006). The other metamorphic unit of the Tvarditsa basement is the Shivachevo complex, initially distinguished as a high-grade/gneissic entity, subsequently retrogressed in greenschist facies conditions (Ivanov et al., 1974). Geochemical and microfabric data (Statelova et al., 2004; Statelova, Machev, 2005) allow to regard the complex as consisting of greenschist facies metagranitoids. All the rocks show a penetrative S- to SW-dipping steep (50-65 ${ }^{\circ}$ mylonitic foliation (Ivanov et al., 1974; Statelova, Machev, 2005; Georgiev et al., 2006), 
developed in greenschist facies (Statelova, Machev, 2005). The Tvarditsa pluton is an E-W elongated body of ca. $80 \mathrm{~km}^{2}$, composed of monzodiorites, granodiorites, biotite and leucocratic aplitoid granites (Ivanov et al., 1974).

The sedimentary cover of the Tvarditsa basement incorporates: i) a Permian section of terrigenous (conglomerates, gravels and sandstones) and vocaniclastic sediments as well as acid volcanics (Ivanov et al., 1974); ii) a complete Lower to Upper Triassic section of terrigenous sediments at the base grading upwards in a limestone-dolomiteargillaceous sequence, which discordantly overlays the basement and Permian rocks; iii) an Upper Cretaceous section, starting with a Turonian flysch alternation, unconformably covered by a Campanian-Maastrichtian limestone-marly sediments; iv) Quaternary deposits of the Tvarditsa basin.

The basement-cover relationships are complicated due to the compressional, generally northvergent Alpine tectonics. The northern contact of the Shivachevo complex with the Lazovo metamorphics and Tvarditsa pluton (Fig. 1) coincides with the E-W trending and S-dipping Strazheranski north-vergent fault zone (Ivanov et al., 1974), recently interpreted as related to the Late JurassicEarly Cretaceous (i.g. early Alpine) tectonics (Georgiev et al., 2006; Gerdjikov et al., 2008). The initial intrusive relationships are preserved only between the Tvarditsa pluton and the host Lazovo complex (Ivanov et al., 1974) as a several tens of meters wide contact aureole sealed the metamorphic fabric. The northern contact between the Lazovo complex and the Permian section (Fig. 1) is mainly of tectonic nature, as in the Lazovo river valley, the metamorphic basement is emplaced over the Permian rocks as decametre-scale thrust imbrications have been observed (Georgiev et al., 2006; Gerdjikov et al., 2008). The deformation induced very low-grade metamorphic transformations and foliation fabric development in the Permian volcano-sedimentary succession. Basing on a structural analogy with similar zones in Zlatitsa Stara Planina Mountain it is concerned as related to the early Aline tectonics. The post-Late Cretaceous age (late Alpine) is proofed for the Sapdere reversed fault (Ivanov et al., 1974), which footwall comprises rocks of the Shivachevo complex as well as Upper Cretaceous sediments, and the hanging wall - the Shivachevo metamorphics only.

\section{Results and regional implication}

Three samples, BU 600 (N 42.709742; E 25.896218) from the Tvarditsa pluton, and BU 601 (N 42.709742; E 25.896218) and BU 602 (N 42.711328; E 25.775397)

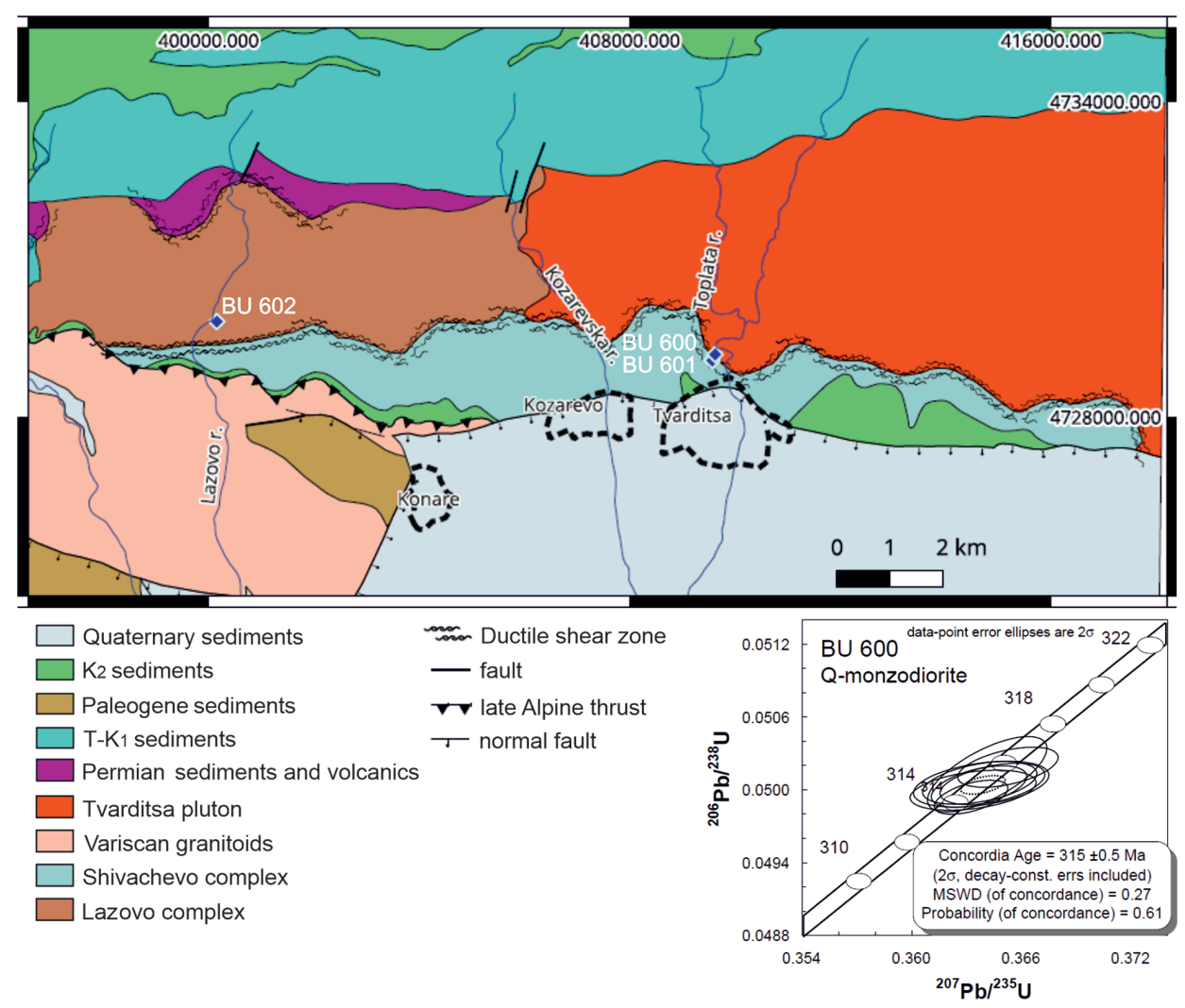

Fig. 1. Geological map of a part of Tvarditsa Stara Planina Mountain, modified after Ivanov et al. (1974) and the Concordia diagram with the analyzed $\mathrm{U}-\mathrm{Pb}$ zircon (TIMS) data of the Tvarditsa pluton 
from the Shivachevo complex are dated (Fig. 1). Sample BU 600 is a quartz monzodiorite, composed of hornblende, biotite, plagioclase, K-feldspar, quartz, and accessories apatite, zircon and titanite. Samples BU 601 and BU 602 are of deformed K-feldspar phyric granitoids, consisting of primary K-feldspar, plagioclase, quartz and biotite (sample BU 602), as in domains of an intense deformation (sample BU 601) these minerals are partially or completely replaced by fine-grained white mica, epidote, quartz, albite and chlorite. The single grain zircon $\mathrm{U}-\mathrm{Pb}$ age determination using isotope dilution thermal ionisation mass spectrometry (IDTIMS) analysis is made as a standard mineral separation technique is applied. The Concordia age of the Tvardtitsa pluton is $315 \pm 0.5 \mathrm{Ma}$ (Fig. 1). Data from samples BU 601 and BU 602 are partly scattered, but the most reliable time of the Shivachevo granitoid emplacement is 319-315 ( $\pm 2-3) \mathrm{Ma}$.

Putting the obtained data in the regional context of the Variscan basement evolution, several important correlations can be made. Although the precision of the structure and age of the Shivachevo complex needs additional studies, from the available and newly obtained data these deformed granitoids are a correlate of similar bodies exposed in the TetevenTroyan part of Stara Planina Mountain referred to as the Ribaritsa (meta)granitoids (Kuykin et al., 1971; Ivanov et al., 1974; Lazarova et al., 2007; Antonov et al., 2010). Similar to the Shivachevo complex, the Ribaritsa unit consists almost entirely of deformed in medium- to high-grade greenschist facies granitoids, which preliminary ${ }^{206} \mathrm{~Pb} /{ }^{238} \mathrm{U}$ age data point to late Carboniferous (313.1 $\pm 4.6 \mathrm{Ma})$ magma emplacement and crystallization (Antonov et al., 2010). Analogous greenschist deformation accommodated the slightly younger (307.8 $\pm 3.9 \mathrm{Ma}) \mathrm{Am}-$ baritsa sheet-like pluton, constituting a considerable part of the Botev Vrah thrust, as it was related to a transpressional tectonics, revealed in the later stage of the Variscan evolution (Balkanska et al., 2021). Furthermore, the greenschist facies Shivachevo complex undoubtedly is a part of the basement of the Stara Planina Zone, since such low-grade metagranitoid units were not recognized in the Sredna Gora Zone basement.

In the Tvarditsa Stara Planina area, the current superposition of the strongly foliated Shivachevo granitoid complex with the undeformed, but a bit younger (?) Tvarditsa pluton suggests significant vertical and horizontal translations along Strazheranski north-vergent fault zone. It is feasible to assume that in the interval $320-315 \mathrm{Ma}$, the protoliths of the Shivachevo complex were more deeply buried than the Tvarditsa granitoids. Obviously, similar to the Ambaritsa granitoids, the Shivachevo metagranites recorded one of the last increments of ductile Variscan tectonics. It is like enough, that the greenschist granitoids were uplifted and transported to the north during the early Alpine orogeny. This hypothesis can be tested via analysis of the clasts in the Permian-Triassic siliciclastis sediments.

The $315 \mathrm{Ma}$ Tvarditsa pluton provides the upper age limit of the high-grade metamorphism in the Lazovo Complex. Structural as well as newly presented geochronological data indicate that the Shivachevo orthometamorphics are an example of a late Variscan granitoid intrusion that recorded the last increments of ductile orogenic processes.

Acknowledgements: We thank our colleagues Dian Vangelov, Neven Georgiev and Julia Statelova for the fruitful field research, ideas and discussion during the study of the geology of the region.

\section{Reference}

Antonov M., S. Gerdjikov, L. Metodiev, Ch. Kiselinov, V. Sirakov, V. Valev. 2010. Explanatory Note to the Geological Map of the Republic of Bulgaria. Scale 1:50 000. Map Sheet K-35-37-B (Pirdop). Sofia, Ministry of Environment and Water, Bulgarian National Geological Survey, 99 p.

Balkanska, E., I. Gerdjikov, S. Georgiev, A. Lazarova, W. Dörr, A. Kounov. 2021. Structural and geochronological constraints on the magmatic and tectonic events in the preAlpine basement of the central parts of the Balkan foldthrust belt (Central Stara Planina Mountains, Bulgaria). Int. J. Earth Sci., 110, 1181-1211; https://doi.org/10.1007/ s00531-021-02011-1.

Georgiev, N., I. Gerdjikov, J. Statelova. 2006. Ductile to brittle-ductile shear zones from the Pre-Mesozoic basement of Tvarditsa Stara Planina area: preliminary field and mesostructural data. - Proc. Nat. Confer. Bulg. Geol. Soc., Geosciences 2006, 94-97.

Gerdjikov, I., N. Georgiev, J. Statelova. 2008. Reworking of basement-cover contact in Tvardishka Stara planina, Central Balkanides. Field Relations and deformational mechanisms. - C. R. Acad. bulg. Sci., 61, 7, 919-926.

Ivanov, Z., K. Kolcheva, S. Moskovski. 1974. Edification géologique d'une partie du noyau de l'anticlinal de Tvarditsa. - Ann. Uni. Sofia, 65, 1-géol., 245-277 (in Bulgarian with French abstract).

Kuykin, S., L. Milanov, J. Gercheva, S. Hristov. 1971. Geological structure of Stara Planina Mountain between Zlatitza and Troyan pass. - Jub. Ann. Geol. Commit., 18, 179-196 (in Bulgarian).

Lazarova, A., N. Georgiev, D. Dimov. 2007. Preliminary structural data on the Stara Planina high-grade metamorphic series, Teteven Stara Planina Mountains. - Proc. Nat. Confer. Bulg. Geol. Soc., Geosciences 2007, 11-13.

Statelova, J. 2006. Variscan high-grade metamorphic rocks in Lazovo complex, Central Stara Planina Mountain. - Proc. Nat. Confer. Bulg. Geol. Soc., Geosciences 2006, 189-192.

Statelova, J., Ph. Machev. 2005. Metagranites from Berkovitsa Group, Central Balkan area - structural and petrographical evidence. - Ann. Uni. Sofia, 97, 1-géol., 149-160.

Statelova, J., Ph. Machev, V. Chavagnac, I. Croudace, A. Milton. 2004. Shivachevo Complex metagranites - geochemical constraints. - Proc. Ann. Confer. Bulg. Geol. Soc., Geology 2004, 69-71. 